\title{
Factors relevant to the prognosis of chronic gastric ulcer
}

\author{
D. W. PIPER, MARGARET GREIG, G. A. E. COUPLAND, ElizABETH HOBbin, \\ AND JANE SHINNERS
}

From the Departments of Medicine and Surgery, University of Sydney, and the Royal North Shore Hospital of Sydney, Sydney, Australia

SUMMARY The factors that determine the recurrence rate of chronic gastric ulcer were studied in 105 patients. It was found that complete healing of the ulcer significantly reduced the recurrence rate and subsequent need for hospital admission because of ulcer symptoms when this group was compared with those who left hospital with their ulcers unhealed. Those admitted with large ulcers also had a higher recurrence rate. The age and sex of the patient, ingestion of analgesics and cigarette smoking did not influence recurrence. The initial healing rate of the ulcer also had no effect on the subsequent course of the patient.

Chronic gastric ulcer remains a major medical problem (Doll and Jones, 1951; Sircus, 1973). Great advances have been made recently in its treatment (Doll, 1964) and diagnosis (Ichikawa, 1973; Kasugai, Ito, and Tsubouchi, 1968; Cotton and Roseberg, 1971; Classen, 1973), and as a consequence, error in diagnosis has virtually been abolished. Treatment may produce symptomatic relief with or without complete ulcer healing and it is not known to what extent either alters the subsequent natural history. The present study defines the effect of complete healing, ulcer size, initial healing rate, age and sex, continued smoking and aspirin intake on the natural history of chronic gastric ulcer.

Received for publication 17 June 1975.

\section{Methods}

\section{PATIENTS STUDIED}

The patients studied were chosen from those admitted to The Royal North Shore Hospital with radiological evidence of a chronic gastric ulcer during 1969 to 1972 inclusive. All spent at least seven days in hospital to exclude those admitted for diagnostic procedures rather than treatment; 243 such patients were admitted during this period.

For the purpose of the present study, patients were excluded if they had radiological evidence of a duodenal ulcer or scar, if they had had previous gastric surgery, or if the ulcer was in a hiatus hernia; 118 were excluded on these criteria. Of the remaining 125, 20 could not be traced, leaving 105 patients who formed the basis of the present study.

\begin{tabular}{|c|c|c|c|c|c|}
\hline \multirow[t]{2}{*}{ Status of Patients } & \multicolumn{5}{|c|}{ Year of Study } \\
\hline & 1969 & 1970 & 1071 & 1072 & Total \\
\hline $\begin{array}{l}\text { Discharged } \\
\text { Unable to be contacted }\end{array}$ & $\begin{array}{r}73 \\
5\end{array}$ & $\begin{array}{r}47 \\
3\end{array}$ & $\begin{array}{r}61 \\
9\end{array}$ & $\begin{array}{r}62 \\
3\end{array}$ & $\begin{array}{r}243 \\
20\end{array}$ \\
\hline $\begin{array}{l}\text { Excluded from study } \\
\text { Surgery initial admission } \\
\text { Coexistent duodenal ulcer } \\
\text { Previous surgery } \\
\text { Gastric ulcer in hiatus hernia } \\
\text { Diagnosis later cancer of the stomach } \\
\text { Dead } \\
\text { Not interviewed }\end{array}$ & $\begin{array}{r}21 \\
7 \\
1 \\
0 \\
0 \\
3 \\
36\end{array}$ & $\begin{array}{c}23 \\
2 \\
3 \\
0 \\
0 \\
11 \\
15\end{array}$ & $\begin{array}{r}15 \\
10 \\
1 \\
1 \\
1 \\
1 \\
23\end{array}$ & $\begin{array}{r}9 \\
7 \\
6 \\
0 \\
1 \\
5 \\
31\end{array}$ & $\begin{array}{r}68 \\
26 \\
11 \\
1 \\
2 \\
10 \\
105\end{array}$ \\
\hline
\end{tabular}

Table I Analysis of ulcer population from which patients studied were selected ${ }^{1}$ Death due to gastric ulcer 
The large number who had operations at the initial admission were those admitted for this purpose alone after rapid recurrence despite routine medical therapy.

\section{FOLLOW UP}

Follow up was initially by postal questionnaire. Information was sought regarding the recurrence of ulcer pain, subsequent admission to hospital because of ulcer symptoms, bleeding, perforation and pyloric stenosis, continued cigarette smoking and analgesic intake, and surgery. All those who complained of abdominal symptoms were subsequently examined radiologically.

During the years $1969,1970,1971$, and 1972, the impatient policy involved the estimation of ulcer size each three weeks in patients in one medical unit and this initial healing rate was subsequently related to the outcome following discharge. Sixty patients were thus studied (table I).

The initial ulcer size (on admission to hospital for the index admission) was related to the subsequent course.

In all instances ulcer size was measured radiologically using the method of Doll, Price, Pygott, and Sanderson (1956). Healing was considered to be present if, to air-contrast radiology, no ulcer crater was present or the ulcer crater was less than $1 \mathrm{sq}$ $\mathrm{mm}$ in surface area at discharge. Also included in the healed group were those patients discharged on carbenoxolone sodium and whose ulcer three weeks from discharge was radiologically proven to be healed.

\section{Results}

EFFECT OF HEALING AND NON-HEALING ON ULCER RECURRENCE AND NEED FOR HOSPITAL ADMISSION

These results are given in table II. It is seen that ulcer recurrence, as judged by barium meal, surgical exploration or the occurrence of haemorrhage or perforation was present in 15 of the $60(25 \%)$ of those discharged with the ulcer healed and 25 of the $45(55 \%)$ discharged with the ulcer unhealed. The better prognosis of those discharged with the ulcer healed is statistically significant $(P=0.001)$.
Similarly those discharged with the ulcer unhealed more frequently required hospital admission because of ulcer symptoms $(P<0.0005)$.

EFFECT OF INITIAL ULCER SIZE ON DISCHARGE STATUS AND RECURRENCE RATE

Ulcers were divided into two groups depending upon whether the initial ulcer size was less than or greater than $51 \mathrm{sq} \mathrm{mm} ; 51 \mathrm{sq} \mathrm{mm}$ was the median ulcer size. The effect of initial ulcer size on the patients' discharge status (healed or unhealed) and subsequent recurrence rate is shown in table III. It is seen that $(a)$ those discharged with the ulcer unhealed more frequently had a large ulcer $(>51 \mathrm{sq}$ $\mathrm{mm})$ on admission (P >0.01); (b) the recurrence rate was twice as common in the unhealed group compared with the healed group regardless of ulcer size. The difference in recurrence rate due to healing compared with non-healing did not reach statistical significance, however, in the small ulcer group.

\begin{tabular}{|c|c|c|c|}
\hline \multirow[t]{2}{*}{ Status of Patients } & \multicolumn{2}{|c|}{ Initial Ulcer Size } & \multirow[t]{2}{*}{ Total $^{1}$} \\
\hline & $\underset{s q m m}{\gtrless 51}$ & $\begin{array}{l}>51 \\
s q \mathrm{~mm}\end{array}$ & \\
\hline $\begin{array}{l}\text { Discharged healed } \\
\text { No. studied } \\
\text { No. with recurrence }\end{array}$ & $\begin{array}{l}31 \\
6(19 \%)\end{array}$ & 20 & $\begin{array}{l}51 \\
13(25 \%)\end{array}$ \\
\hline $\begin{array}{l}\text { Discharged unhealed } \\
\text { No. studied } \\
\text { No. with recurrence }\end{array}$ & $\begin{array}{l}9 \\
4(44 \%)\end{array}$ & $\begin{array}{l}21 \\
15(71 \%)\end{array}$ & $\begin{array}{l}30 \\
19(63 \%)\end{array}$ \\
\hline
\end{tabular}

Table III Effect of ulcer size and ulcer healing on recurrence rate

${ }^{1}$ The number included in this table (81 patients) is less than the total studied ( 105 patients) because in 24 the initial barium meal was not available to measure ulcer size.

EFFECT OF INITIAL ULCER HEALING RATE ON RECURRENCE RATE

Sixty patients had the initial ulcer healing rate determined while in hospital and were subsequently studied. The follow-up results are shown in table IV. It is seen that slow initial healing did not correlate with rapid recurrence, the percentage with recurrence being almost identical whether the ulcer healed initially in three, six or nine weeks $(P=0.9)$.

\begin{tabular}{|c|c|c|c|c|c|c|c|c|c|c|}
\hline & \multicolumn{4}{|l|}{ Year } & \multirow[t]{2}{*}{ Total } & \multicolumn{4}{|l|}{ Year } & \multirow[t]{2}{*}{ Total } \\
\hline & 1969 & 1970 & 1971 & 1972 & & 1969 & 1970 & 1971 & 1972 & \\
\hline $\begin{array}{l}\text { No. studied } \\
\text { No. with recurrence } \\
\text { No. admitted to hospital }\end{array}$ & $\begin{array}{r}18 \\
6 \\
6\end{array}$ & $\begin{array}{r}13 \\
3 \\
1\end{array}$ & $\begin{array}{r}18 \\
6 \\
2\end{array}$ & $\begin{array}{r}11 \\
0 \\
1\end{array}$ & $\begin{array}{l}60 \\
15(25 \%) \\
10(17 \%)\end{array}$ & $\begin{array}{l}18 \\
12 \\
13\end{array}$ & $\begin{array}{l}2 \\
1 \\
1\end{array}$ & $\begin{array}{l}5 \\
2 \\
2\end{array}$ & $\begin{array}{r}20 \\
10 \\
7\end{array}$ & $\begin{array}{l}45 \\
25(55 \%) \\
23(51 \%)\end{array}$ \\
\hline
\end{tabular}

Table II Effect of healing and non-healing on ulcer recurrence and hospital admission 


\begin{tabular}{llllll}
\hline Ulcer State on Follow Up & \multicolumn{2}{l}{ Initial Healing Rate } & Total \\
\cline { 2 - 4 } & Healed in Three Weeks & Healed in Six Weeks & Healed in Nine Weeks & \\
\hline Number & 28 & $23(26 \%)$ & 9 & 60 \\
Recurrent ulcer & $6(21 \%)$ & $6(22 \%)$ & $14(23 \%)$ \\
\hline
\end{tabular}

Table IV Effect of initial healing rate on recurrence rate

\begin{tabular}{|c|c|c|c|c|}
\hline & \multicolumn{2}{|l|}{ Aspirin } & \multicolumn{2}{|l|}{ Cigarettes } \\
\hline & No Aspirin & Aspirin Ingestion & Non-smokers & Smokers \\
\hline $\begin{array}{l}\text { Total no. } \\
\text { No. with recurrence } \\
\text { Significance of difference due to aspirin or } \\
\text { smoking }\end{array}$ & $\begin{array}{l}41 \\
16(39 \%) \\
\chi^{2}=0.02 \mathrm{P}\end{array}$ & 64 (38\%) & $\begin{array}{l}44 \\
13(30 \%) \\
x^{2}=2 \cdot 35 \text { P } 0\end{array}$ & $\begin{array}{l}61 \\
27(44 \%)\end{array}$ \\
\hline
\end{tabular}

Table V Effect of analgesic ingestion and cigarette smoking on ulcer recurrence

\begin{tabular}{|c|c|c|c|c|}
\hline \multirow[t]{2}{*}{ Sex and $A g e^{1}$} & \multicolumn{2}{|l|}{ Ulcer Size } & \multicolumn{2}{|c|}{ Recurrent Ulcer } \\
\hline & $\gtrless 51 \mathrm{sq} \mathrm{mm}$ & $>51 \mathrm{sq} \mathrm{mm}$ & Recurrence & Non-recurrence \\
\hline $\begin{array}{l}>60 \text { years } \\
<59 \text { years }\end{array}$ & $\begin{array}{l}19 \\
21\end{array}$ & $\begin{array}{l}19(50 \%) \\
22(51 \%)\end{array}$ & $\begin{array}{l}20(40 \%) \\
20(37 \%)\end{array}$ & $\begin{array}{l}30 \\
35\end{array}$ \\
\hline
\end{tabular}

Table VI Relationship of sex and age to ulcer size and ulcer recurrence

${ }^{1}$ The effect of age and sex on ulcer size and ulcer recurrence did not reach statistical significance (P $\left.>0 \cdot 1\right)$.

\section{EFFECT OF HISTORY OF CONTINUED}

ANALGESIC INGESTION AND CIGARETTE

SMOKING ON ULCER RECURRENCE

The results are shown in table $V$. It is seen that neither continued analgesic ingestion nor cigarette smoking influenced ulcer recurrence.

\section{EFFECT OF SEX ON INITIAL ULCER SIZE} AND ULCER RECURRENCE

This comparison is shown in table VI. It is seen that the sex of the patient did not influence the initial ulcer size or frequency of the ulcer recurrence.

\section{EFFECT OF AGE ON ULCER SIZE AND RECURRENCE}

The age of the patient had no effect on initial ulcer size or the recurrence rate (table VI).

\section{Discussion}

There are many studies relating to the course of chronic gastric ulcer and in most of these a similar trend exists. The most relevant to the present study is the detailed and extensive study conducted by the Veterans Administration (Littman, 1971; Hanscom and Buchman, 1971; Sun and Stempien, 1971). The

\begin{tabular}{|c|c|c|}
\hline Factor Studied & $\begin{array}{l}\text { Veterans } \\
\text { Administration Study }\end{array}$ & $\begin{array}{l}\text { Royal North Shore } \\
\text { Hospital, Sydney }\end{array}$ \\
\hline $\begin{array}{l}\text { Complete healing } \\
\text { Ulcer size }\end{array}$ & $\begin{array}{l}\text { Reduced recurrence } \\
\text { No effect }\end{array}$ & $\begin{array}{l}\text { Reduced recurrence } \\
\text { Recurrence greater } \\
\text { with large ulcers }\end{array}$ \\
\hline $\begin{array}{l}\text { Age } \\
\text { Sex } \\
\text { Initial healing rate } \\
\text { Aspirin } \\
\text { Cigarette smoking } \\
\text { Coexistent duodenal }\end{array}$ & $\begin{array}{l}\text { No effect } \\
\text { Not studied } \\
\text { Not settled } \\
\text { Not studied } \\
\text { Not studied }\end{array}$ & $\begin{array}{l}\text { No effect } \\
\text { No effect } \\
\text { No effect } \\
\text { No effect } \\
\text { No effect }\end{array}$ \\
\hline $\begin{array}{l}\text { ulcer } \\
\text { Site of ulcer }\end{array}$ & $\begin{array}{l}\text { Increased recurrence } \\
\text { No relationship }\end{array}$ & $\begin{array}{l}\text { Excluded from study } \\
\text { Not studied }\end{array}$ \\
\hline
\end{tabular}

Table VII Comparison of findings in present study with those of Veterans Administration on recurrence after healing

results of the latter study and the present study are compared in table VII. Relevant to these two studies and other studies, the following findings justify comment.

\section{RECURRENCE RATE}

Gott, Shapiro, and Kelty (1954) observed 86 patients whose ulcers had healed medically; two to five years later 14 had recurred. Baume, Hunt, and Piper (1972) observed a recurrence rate of $77 \%$ after initial 
complete healing within two years in a placebotreated group of gastric ulcer patients. Dworken, Roth, Duber, and Berger (1957) observed a recurrence rate of $80 \%$ in 135 patients followed for 3.9 years after healing of the ulcer.

There are numerous studies referring to the status of gastric ulcer patients at varying periods after their diagnosis without their status as regards healing or non-healing on discharge being defined. The early literature is summarized by Ivy, Grossman, and Bachrach (1950); they observed in 11 published series that the recurrence rate varied between 19 and $87 \%$ at the end of two years. A more recent survey has been made by Dworken et al (1957) with an essentially similar scatter of recurrence rates. In the context of this report, little is gained by reviewing the voluminous literature, except to appreciate the poor prognosis for chronic gastric ulcer. In the present study the recurrence rate was $25 \%$ in those discharged healed and $55 \%$ in those discharged unhealed. The difference due to healing or non-healing on discharge reached statistical levels over the whole series and in the large ulcer group but in the small ulcer group the adverse effect of non-healing did not reach a statistically significant level.

\section{ULCER SIZE}

In the present study, as in others (Hanscom and Buchman, 1971; Sun and Stempien, 1971), the effect of ulcer size and failure to heal initially are intertwined; our observations showed initial large ulcer size adversely influenced recurrence but this effect was not observed in the Veterans Administration study (Hanscom and Buchman, 1971; Sun and Stempien, 1971).

\section{INITIAL HEALING RATE}

As Richardson has pointed out, if it could be ascertained that slow healing and rapid recurrence were related, it might be reasonable to recommend early surgery for those ulcers that heal slowly, ie, not healed in six weeks (Richardson, 1973). However, the present study failed to show this relationship. It is noted, however, that Flood and Hennig (1950) found a slightly poorer outcome in those with a slower healing rate. The Veterans Administration study did not produce a conclusive result regarding this fact.

\section{AGE AND SEX}

Our findings agree with those of the Veterans Administration study (Hanscom and Buchman, 1971) and those of Krag (1966) that age had no effect on the recurrence rate. Flood and Hennig (1950) and Swynnerton and Tanner (1953), however, found that younger patients did worse than older patients. In the present study, sex had no effect on the outcome, thereby agreeing with the findings of Flood and Hennig (1950) and differing from the observations of Krag (1966) who found that men had a poorer prognosis.

\section{CIGARETTE SMOKING AND ANALGESIC} INGESTION

The failure of cigarette smoking to influence adversely the course of peptic ulcer was not unexpected in view of recent data (Whitecross, Clarke, and Piper, 1973) but the lack of effect of analgesic ingestion was unexpected, considering the data available to the contrary, especially in Australia (Baume et al, 1972; Duggan, 1972).

This study demonstrates the beneficial effect that may result from complete healing of a gastric ulcer by medical treatment, the morbidity due to gastric ulcer being approximately halved. If we accept the findings of Emery and Monroe (1935) that approximately $2.4 \%$ of gastric ulcer patients died of their complications over an average period of 3.9 years (similar and higher mortalities have been reported by other workers, reviewed by Dworken et al, 1957), the emphasis must be placed on the necessity for complete healing if an acceptable mortality, and likewise morbidity, is to be obtained. This is particularly so when, in skilled hands, surgical treatment of gastric ulcer carries a mortality of $0.2 \%$ (Callum and Talbot, 1973; Duthie and Kwong, 1973; Nielsen, Amdrup, Christiansen, Fenger, Jensen, Lindskov, and Nielsen, 1973). It is our current policy to heal all gastric ulcers completely by medical means (hospital admission or carbenoxolone sodium) and if the lesion recurs within two years surgery is advised (Piper, Coupland, Fevre, Hunt, Kasumi, Nagy, and Wood, 1974).

We wish to thank the Ramaciotti Foundations whose support made this work possible, and to the many physicians and surgeons who gave us access to their patients.

\section{References}

Baume, P. E., Hunt, J. H., and Piper, D. W. (1972). Glycopyrronium bromide in the treatment of chronic gastric ulcer. Gastroenterology, 63, 399-406.

Callum, K. G., and Talbot, J. E. (1973). The surgical treatment of peptic ulcer: a 15 year review. Brit. J. Surg., 60, 511-516.

Classen, M. (1973). Endoscopy in benign peptic ulcer. Clin. Gastroent., 2, 315-327.

Cotton, P. B., and Rosenberg, M. T. (1971). Fiberendoscopy of the upper gastrointestinal tract. Brit. J. hosp. Med., 6, Suppl., 52.

Doll, R. (1964). Medical treatment of gastric ulcer. Scot. med. J., 9, 183-196.

Doll, R., and Jones, F. A. (1951). Occupational factors in the aetiology of gastric and duodenal ulcers. Spec. Rep. Ser. med. Res. Counc., No. 276. HMSO, London.

Doll, R., Price, A. V., Pygott, F., and Sanderson, P. H. (1956). Continuous intragastric milk drip in the treatment of uncomplicated gastric ulcer. Lancet, 1, 70-73. 
Duggan, J. M. (1972). Aspirin ingestion and perforated peptic ulcer. Gut, 13, 631-633.

Duthie, H. L., and Kwong, N. K. (1973). Vagotomy or gastrectomy for gastric ulcer. Brit. med. J., 4, 79-81.

Dworken, H. J., Roth, H. P., Duber, H. C., and Berger, D. G. (1957). Observations on the course of benign gastric ulcer and factors affecting its prognosis. Gastroenterology, 33, 880-897.

Emery, R. S., and Monroe, R. T. (1935). Peptic ulcer: nature and treatment based on a study of one thousand four hundred and thirty five cases. Arch. intern. Med., 55, 271-292.

Flood, C. A., and Hennig, G. C. (1950). Recurrence in gastric ulcer under medical management. Gastroenterology, 16, 57-72.

Gott, J. R., Shapiro, D., and Kelty, K. C. (1954). Gastric ulcer: a study of 138 patients. New Engl. J. Med., 250, 499-504.

Hanscom, D. H., and Buchman, E. (1971). The Veterans Administration cooperative study in gastric ulcer: the follow up period. Gastroenterology, 61, 585-591.

Ichikawa, H. (1973). Differential diagnosis between benign and malignant ulcers of the stomach. Clin. Gastroent., 2, 329-343.

Ivy, A. C., Grossman, M. I., and Bachrach, W. H. (1950). Peptic Ulcer, p. 913. Churchill, London.

Kasugai, T., Ito, E., and Tsubouchi, M. (1968). Gastric biopsy under direct vision. Stomach and Intestine (Tokyo), 3, 1211.
Krag, E. (1966). Long term prognosis in medically treated peptic ulcer: a clinical, radiographic and statistical follow-up study. Acta Med. scand., 180, 657-670.

Littman, A. (1971). The Veterans Administration cooperative study in gastric ulcer: goals and design. Gastroenterology, 61, 567-569.

Nielsen, J., Amdrup, E., Christiansen, P., Fenger, C., Jensen, H. A., Lindskov, J., and Nielsen, S. A. D. (1973). Gastric ulcer. II. Surgical treatment. Acta chir. scand., 139, 460-465.

Piper, D. W., Coupland, G. A. E., Fevre, D. I., Hunt, J., Kasumi, A., Nagy, G. S., and Wood, H. D. (1974). General management of peptic ulcer. In New Ethicals Patient Management, Sept.

Richardson, C. T. (1973). Chronic gastric ulcer. In Gastrointestinal Disease, Pathology, Diagnosis and Management, 1st ed., edited by M. H. Sleisenger and J.S. Fordtran, p. 692. Saunders, Philadelphia, London, Toronto.

Sircus, W. (1973). Foreword. In Clin. Gastroent., 2, 217-218.

Sun, D. C. H., and Stempien, S. J. (1971). The Veterans Administration cooperative study in gastric ulcer: site and size of the ulcer as determinants of outcome. Gastroenterology, 61, 576-584.

Swynnerton, B. F., and Tanner, N. C. (1953). Chronic gastric ulcer. Brit. med J., 2, 841-847.

Whitecross, D. P., Clarke, A. D., and Piper, D. W. (1973). The effect of cigarette smoking on human gastric secretion. Scand. $J$. Gastroent., 5, 399-403. 